\title{
Fertility Study
}

National Cancer Institute

\section{Source}

National Cancer Institute. Fertility Study. NCI Thesaurus. Code C15413.

Research to investigate issues regarding reproductive processes. 